\title{
Nemi különbségek a dohányzás gyakoriságában hazánkban 2010 és 2018 között
}

\author{
Kékes Ede dr. ${ }^{1}$ - Barna István dr. ${ }^{2}$ \\ Daiki Tenno dr. ${ }^{3}$. Dankovics Gergely dr. ${ }^{4}$
}

'Pécsi Tudományegyetem, Általános Orvostudományi Kar, I. Belgyógyászati Klinika, Pécs

${ }^{2}$ Semmelweis Egyetem, Általános Orvostudományi Kar, I. Belgyógyászati Klinika, Budapest

${ }^{3}$ Eötvös Loránd Tudományegyetem, Média és Oktatásinformatikai Tanszék, Budapest

${ }^{4}$ Magyarország Átfogó Egészségvédelmi Szűrőprogramja, Budapest

Bevezetés: A dohányzás káros hatásai jelentős népegészségügyi kérdést jelentenek az egész világon.

Célkitüzés: A Magyarország Átfogó Egészségvédelmi Szürőprogramja 2010-2020-2030 (MÁESZ) keretében a 2010 és 2018 közötti időszakban végzett szűrések eredményeinek bemutatása és összevetése a nemzetközi adatokkal. Módszer: A 9 éves, folyamatos szürés során 71922 nő és 60934 férfi adatait elemeztük a 18-80 év közötti populációban, és vizsgáltuk a napi rendszerességgel dohányzók előfordulását. Az adatok gyưjtése speciális szűrési adatlapok segítségével történt asszisztencia mellett.

Eredmények: A 9 év átlagában a szürésen megjelentek közül a férfiak 24,4\%-a, a nók 24,2\%-a rendszeresen dohányzik. A dohányzás prevalenciája 2012 és 2015 között átmeneti szignifikáns csökkenést mutatott, majd 2016-tól újra emelkedni kezdett. A hullámvölgy egybeesik a nemzeti dohányboltok nyitási időszakával. Férfiaknál a fiatal felnőtt korban (18-25 év) szignifikánsan nagyobb volt a dohányzók aránya, mint a nóknél. A késóbbi életszakaszban a különbség kiegyenlítődött, sőt 46-55 év között a nőknél volt nagyobb, a dohányzás prevalenciája. A két nem között a dohányzási szokásokban eltérés áll fenn, ami a nőknél feltehetően a házassággal, anyasággal hozható összefüggésbe. 56 éves kor után mindkét nem esetében rohamosan csökkent a dohányzók aránya. A magyarországi dohányzásprevalenciaátlagok minden korcsoportban szignifikánsan meghaladják az európai és világátlagokat. A középkorú nőknél észlelt átmeneti emelkedést az európai felmérésnél is leírták.

Következtetések: Hazánkban 2010-hez képest a dohányzók aránya csökkent, de a 2015 után észlelt újabb emelkedési hullám nem kedvező jelenség. Aggasztónak találjuk a dohányzó nők magas arányát.

Orv Hetil. 2019; 160(52): 2047-2053.

Kulcsszavak: dohányzás, egészségszűrés, felnőtt populáció, nemi különbségek, Magyarország

\section{The prevalence of smoking and gender differences according to the data of the national health screening program in 2010-2018 in Hungary}

Introduction: The harmful effects represent an important public health problem in tha world.

Aim: Our aim is to report and compare the results of screenings performed in Hungary's Comprehensive Health Screening Program 2010-2020-2030 (MÁESZ) with international data.

Method: During the 9-year continuous screening, we analyzed the data of 71922 women and 60934 men in the 18-80-year-old population and examined the occurrence of regular daily smokers. Data were collected with the help of special screening data sheets.

Results: $24.4 \%$ of males and $24.2 \%$ of females smoked regularly during the 9 -year screening period. Between 2012 and 2015, smoking prevalence showed a temporary significant decline, then, from 2016, it started to increase again. The downturn coincided with the opening of national tobacco stores. In men, the proportion of smokers was significantly higher in young adults (18-25 years) than in women. Later in life, the difference leveled off and even between $46-55$ years, the prevalence of smoking was greater in women. There is a difference in smoking patterns between the two genders, which is probably related to marriage and motherhood in women. After 56 years, the proportion of smokers in both genders decreased rapidly. The prevalence of smoking in Hungary in all age groups 
significantly exceeds the European and world average. Transient increases in middle-aged women have also been reported in European surveys.

Conclusion: Compared to 2010, the proportion of smokers has decreased in Hungary, but a new surge observed after 2015 is not a positive phenomenon. We find the high proportion of smoking women worrying.

Keywords: smoking, health screening, adult general population, gender differences, Hungary

Kékes E, Barna I, Daiki T, Dankovics G. [The prevalence of smoking and gender differences according to the data of the national health screening program in 2010-2018]. Orv Hetil. 2019; 160(52): 2047-2053.

(Beérkezett: 2019. augusztus 29.; elfogadva: 2019. szeptember 19.)

\begin{abstract}
Rövidítések
COPD $=$ (chronic obstructive pulmonary disease $)$ krónikus obstruktív tüdőbetegség; $\mathrm{CI}=$ (confidence interval) konfidenciaintervallum; $\mathrm{CV}=$ cardiovascularis; $\mathrm{ELEF}=$ Európai Lakossági Egészségfelmérés; $\mathrm{EU}=$ Európai Unió; $\mathrm{FEV}_{1}=$ (forced vital capacity in 1 second) az első másodpercre eső erőltetett kilégzési térfogat; hsCRP $=($ high sensitivity $\mathrm{C}$-reactive protein) nagy szenzitivitású C-reaktív protein; MÁESZ = Magyarország Átfogó Egészségvédelmi Szűrőprogramja; NO = nitrogénmonoxid; WHO = (World Health Organization $)$ Egészségügyi Világszervezet
\end{abstract}

A dohányzás az egészségkárosodás egyik világméretû kockázati tényezője. A cigaretta és egyéb dohánytermékek számos káros anyagot tartalmaznak gáz és kátrány formájában, melyek szövetkárosító, valamint carcinogen hatásúak is. Ezeken belül különböző hidrokarbonátokat (izoprén, benzol, benzopirén), valamint kiemelkedően nikotint, szén-monoxidot, nitrogén-oxidot, hidrogéncianidot és számos preoxidatív fémet (kadmium, vas, higany, nikkel, vanádium) is tartalmaz. Mindezeken túl szabadoxigén-gyökök jelenléte is egyértelmúen kimutatható [1]. Szervezetünkben a dohányzás során bekerülő kémiai anyagok strukturális és funkcionális károsodásokat idéznek elő a szívben, a tüdőben és az érrendszerben, valamint elősegítik a korai érelmeszesedés kialakulását, kedvezőtlen irányba tolják el a lipidprofilt is. A vascularis rendszer vonatkozásában a fö ok az oxidatív stressz kialakulása, a NO-hatás inaktiválása és ezáltal az endotheldiszfunkció megjelenése. A strukturális elváltozások a dohányzás elkezdésekor azonnal érvényesülnek, de sokáig nem kerülnek felismerésre, „maszkírozott” formában maradnak, majd hirtelen - egy klinikai kórkép formájában (ischaemiás szívbetegség, hypertonia, érszúkület, krónikus obstruktív tüdőbetegség [COPD], emphysema, tüdőcarcinoma) - jelennek meg [2-5]. Bizonyítást nyert az is, hogy a cigarettafogyasztás közvetlenül gátolja szervezetünk legnagyobb vasodilatatorának, a nitrogén-oxidnak a hasznosulását [6]. Újabban a hsCRP-szint emelkedését is kimutatták [7]. A károsító hatások közé tartozik a felső légutak tartós irritációja, a légúti áramlás lassan fokozódó akadályozottsága és a tüdőparenchyma pusztulása és ezzel együtt a légzésfunkciós paraméterek romlása (vitálkapacitás, légzési térfogat, $\mathrm{FEV}_{1}$ stb.), a pulmonalis artériás nyomás növekedése, a védekezőme- chanizmusok csökkenése légúti infekciók ellen [1]. Azokban az országokban, ahol évtizedek óta jelentős mértékü a dohányzás, a tüdőcarcinoma 90-95\%-áért (nőknél 70-80\%), az összes rákhalálozás 30-35\%-ért, a COPD okozta halálozás 80-85\%-áért (nôkknél 70-75\%), míg a cardiovascularis (CV-) mortalitás 20-25\%-áért felelős [8-10]. A dohányzás különösen károsan befolyásolja a már kialakult CV-betegségeket, a diabetest, és elősegíti azok progresszióját [11].

Ami a dohányzás előfordulását illeti, két felmérés adatai a legmegbízhatóbbak. Az egyik a Global Burden of Disease Study 2015 [12], melyben 195 ország adatainak összesítése szerint világunkban az életkorrra korrigált prevalencia a felnőtt férfiaknál 25\% (95\% CI 24,2-25,7), a nőknél 5,4\% (95\% CI 5,1-5,7); az egyes országok között azonban jelentôs eltérések állnak fenn. A másik a 2017. évi WHO-riport [13], melyben más megközelítésben - a gazdasági fejlettség alapján - mutatják be az adatokat, de globálisan hasonló adatokkal találkozunk, azzal a különbséggel, hogy az előfordulást férfiaknál 35\%-ra, nőknél 6\%-ra becsülik. Számos országban a nőknél a globális átlagnál jóval nagyobb a dohányzók aránya, így hazánkban is $[13,14]$. Az Eurostat legutolsó adata szerint, mely a 2014. évi ELEF-felmérést tükrözi, a folyamatosan naponta dohányzók aránya $32 \% / 21 \%$ (férfi/ nő) $[15,16]$. Magyarország Átfogó Egészségvédelmi Szűrőprogramja 2010-2020-2030 (MÁESZ) lehetőséget adott számunkra, hogy a hazai előfordulást részletesen, nagy populációban vizsgáljuk.

\section{Betegek és módszer}

A MÁESZ 2010-ben indult, $10+10$ évre tervezett, primer és szekunder prevenciót folyamatosan szolgáló program, 9 éve múködik (www.egeszseg program.eu). Alapeleme egy - 74 szakmai szervezet által összeállított komplex szúrés elvégzésére alkalmas - speciálisan erre a célra kialakított szürőkamion, melyben az egyén (18 éven felüliek) a személyes kikérdezése és 37-féle vizsgálat során képet kap egészségállapotáról, aktuális kockázatairól, illetve addig nem ismert esetleges betegségéről. Öszszefoglaló adatait egy egészségkönyvben rögzítve kézhez kapja, és bemutathatja háziorvosának a további teendők érdekében, de már helyben, a szürókamionnál is lehetô" sége van felvilágosítást és útbaigazítást kérni egészségi 
állapotáról. A szűrőegység egész évben tartó folyamatos múködéssel az ország minden tájára - homogén eloszlással - eljut a nagyvárosoktól a kis falvakig [17].

A szűrővizsgálat során 2010 és 2018 között 71922 nő és 60934 férfi adatai kerültek részletes elemzésre. A betegek alapadatait szürési kérdőlap segítségével vettük fel asszisztensi felügyelettel. A dohányzás elemzése során csak azokat vettük figyelembe, akik napi rendszerességgel fogyasztottak dohánytermékeket (cigaretta, szivar, pipa). 54449 nem dohányzó (átlagéletkor 43,1 \pm 13,8 év) és 17473 dohányzó (átlagéletkor 40,2 $\pm 13,5$ év) nő, valamint 46027 nem dohányzó (átlagéletkor 41,3 \pm 12,6 év) és 14907 dohányzó (átlagéletkor 37,2 $\pm 13,1$ év) férfi adatait elemeztük. Az adatokat anonim módon az aLLCare-Stat adatbázis-kezelő, elemző és kockázatbecslő programban tároltuk, illetve dolgoztuk fel, és standard statisztikai elemzést végeztünk.

\section{Eredmények}

A szüréseken 18 és 80 év közötti életkorú egyének jelentek meg, akiknek az életkori eloszlását az 1 . ábra mutatja. A 2010 és 2018 közötti összes szűrt egyén esetében a dohányzók átlagos előfordulási gyakorisága nőknél $24,29 \%$, férfiaknál 24,4\%. A vizsgált időszakban - éves bontásban - 2010-2011-ben az előfordulás 26\% és 27\% között változott, majd 2012 és 2015 között szignifikáns

\begin{tabular}{lcc}
\hline Korcsoport (év) & Nók (\%) & Férfiak (\%) \\
\hline $18-25$ & 10,35 & 9,73 \\
$26-35$ & 25,49 & 32,13 \\
$36-45$ & 25,73 & 28,15 \\
$46-55$ & 19,92 & 16,1 \\
$56-65$ & 12,73 & 10,24 \\
$66-75$ & 4,61 & 2,82 \\
$76-$ & 1,12 & 0,79 \\
\hline
\end{tabular}

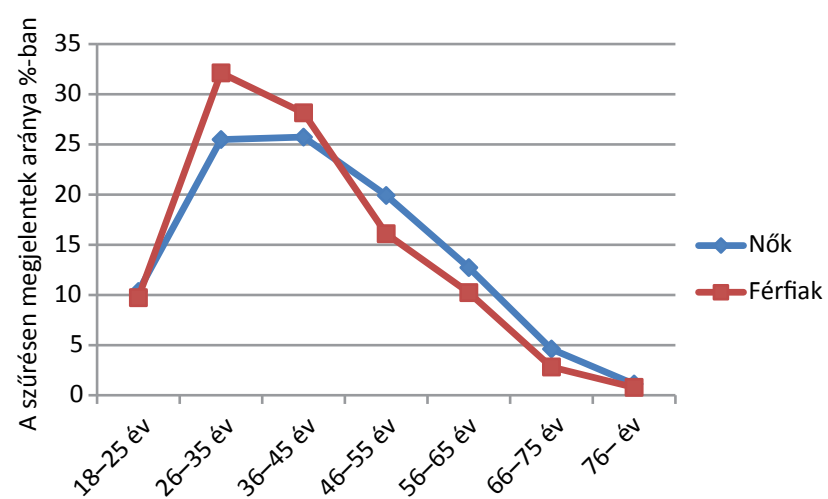

1. ábra

A szűrésen megjelentek korcsoportok szerinti bontásban az öszszes eset százalékában mindkét nemben

\begin{tabular}{lccccccccc}
\hline & 2010 & 2011 & 2012 & 2013 & 2014 & 2015 & 2016 & 2017 & 2018 \\
\hline Nók & 25,4 & 25,8 & 23,7 & 22,9 & 23,8 & 22,4 & 24,3 & 25,3 & 23,6 \\
Férfiak & 26,5 & 25,8 & 22,9 & 24,1 & 24,1 & 22,7 & 23,8 & 25,4 & 24,4 \\
\hline
\end{tabular}

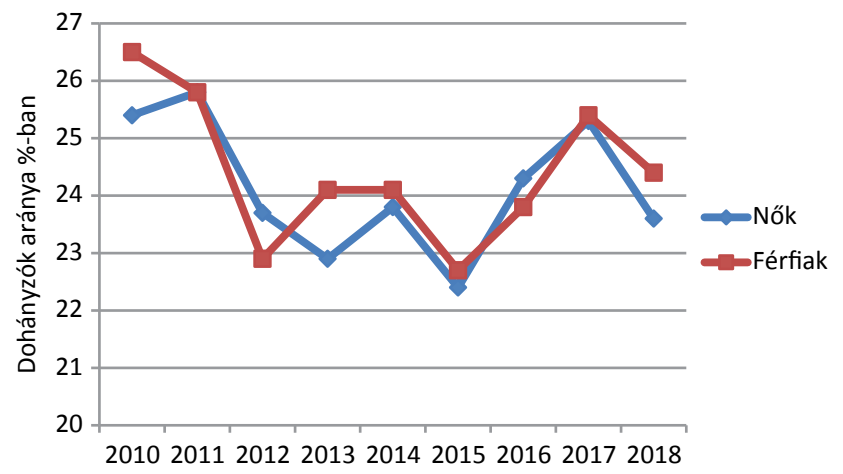
\begin{tabular}{l|l} 
2. ábra & $\begin{array}{l}\text { A dohányzók aránya a szưrésen megjelentek százalékában } 2010 \\
\text { és } 2018 \text { között }\end{array}$
\end{tabular}

$(\mathrm{p}<0,01)$ hullámvölgyet észleltünk; ezt követően újra emelkedett (2. ábra).

A korcsoportbontás során a teljes 8 év összes adata szerint a 18-25 éves korcsoportban a legnagyobb a dohányzók aránya mindkét nemben, férfiaknál szignifikánsan $(\mathrm{p}<0,001)$ nagyobb, mint nőknél. Ezt követően férfiaknál a kor előrehaladásával párhuzamosan csökken a dohányzók aránya, míg nők esetében a 46-55 közti években szignifikáns átmeneti emelkedés van. 56 éves kor után a dohányzók aránya mindkét nemben rohamosan csökken (1. táblázat).

Megvizsgáltuk, hogy a fó munkaképes életkorcsoportokban - 18-55 év - milyen a dohányzók aránya az egyes években 2010 és 2018 között. Minden évben egyező jellegú változásokat figyeltünk meg. Nők esetében a legnagyobb a dohányzók gyakorisága 18-25 év között. Ezt követően 26-45 év között csökkent az arány, majd 4655 év között újra szignifikánsan $(\mathrm{p}<0,001)$ emelkedett (3. ábra). Férfiaknál mind a 8 évben a dohányzók aránya ugyancsak a 18-25 év közöttieknél a legnagyobb, jóval 30\% feletti. Ebben a korcsoportban a dohányzók gyakorisága szignifikánsan $(\mathrm{p}<0,001)$ nagyobb, mint nők ese-

1. táblázat |A dohányzók aránya korcsoportos bontásban a teljes vizsgálati anyagban (2010-2018)

\begin{tabular}{lccc}
\hline $\begin{array}{l}\text { Korcsoport } \\
(\text { év })\end{array}$ & $\begin{array}{c}\text { Dohányzó } \\
\text { Nók }(\%)\end{array}$ & $\begin{array}{c}\text { Dohányzó } \\
\text { Férfiak }(\%)\end{array}$ & p-érték \\
\hline $18-25$ év & 29,6 & 34,5 & $<0,001$ \\
$26-35$ & 26,5 & 28,6 & $<0,05$ \\
$36-45$ & 23,1 & 22,4 & ns \\
$46-55$ & 27,9 & 21,1 & $<0,001$ \\
$56-65$ & 18,9 & 17,1 & ns \\
$66-75$ & 6,8 & 6,2 & ns \\
$76-$ & 4,7 & 5,9 & $<0,05$ \\
\hline
\end{tabular}




\begin{tabular}{rlllllllll}
\hline Nók & 2010 & 2011 & 2012 & 2013 & 2014 & 2015 & 2016 & 2017 & 2018 \\
\hline $18-25$ év & 35,8 & 32,1 & 28,2 & 26,1 & 28,6 & 25,5 & 30,9 & 30,8 & 26,4 \\
$26-35$ év & 29,2 & 28,8 & 24,8 & 24,3 & 26,9 & 24,9 & 25,9 & 28 & 25,3 \\
$36-45$ év & 27,6 & 26 & 23,4 & 22,6 & 23,8 & 21,5 & 22,3 & 24,1 & 23,3 \\
$46-55$ év & 29,5 & 29,3 & 26,1 & 26,9 & 26,2 & 26,1 & 28,1 & 27,9 & 28,1
\end{tabular}

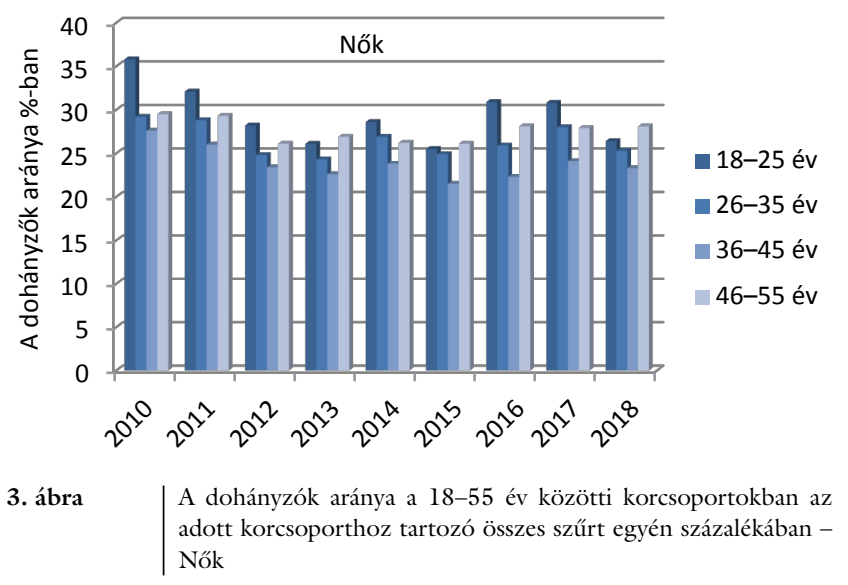

\begin{tabular}{ccccccccccc}
\hline Férfiak & 2010 & 2011 & 2012 & 2013 & 2014 & 2015 & 2016 & 2017 & 2018 \\
\hline $18-25$ év & 39,5 & 34,2 & 31 & 38,1 & 33,9 & 30,8 & 33,1 & 35 & 35,5 \\
$26-35$ év & 33,7 & 30,6 & 26,1 & 27,1 & 29,5 & 26,3 & 28,3 & 29,4 & 27,1 \\
$36-45$ év & 25,1 & 25,9 & 21,1 & 22,1 & 20,7 & 20,4 & 21,5 & 22,8 & 22,5 \\
$46-55$ év & 24,3 & 21,6 & 21,5 & 20,7 & 22,7 & 21,8 & 20,2 & 22,8 & 21,4 \\
\hline
\end{tabular}

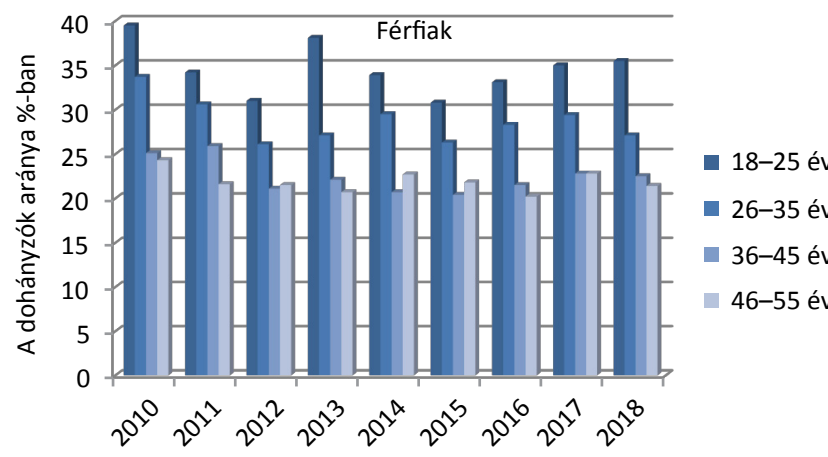

4. ábra $\mid$ A dohányzók aránya a 18-55 év közötti korcsoportokban az adott korcsoporthoz tartozó összes szứrt egyén százalékában Férfiak

tében. Minden további korcsoportban egyenletes, folyamatos csökkenés figyelhetô meg (4. ábra).

A 2016 és 2018 között bekövetkezett újabb fogyasztásemelkedés időszakában összehasonlítottuk a dohányzó nők és férfiak arányát az aktív munkaképes - 18 és 55 év közötti - életszakaszokban. Itt két szignifikáns különbség figyelhető meg: egyrészt 18-25 év között a férfiaknál szignifikánsan nagyobb a dohányzók aránya $(\mathrm{p}<0,01)$, másrészt érvényesült az a trend, hogy a nők 46-55 éves korban szignifikánsan $(\mathrm{p}<0,01)$ többen fogyasztanak dohánytermékeket (5. ábra).

\begin{tabular}{lcllccc}
\hline & N2016 & N2017 & N2018 & F2016 & F2017 & F2018 \\
\hline 18-25 év & 30,9 & 30,8 & 26,4 & 33,1 & 35 & 35,5 \\
$26-35$ év & 25,9 & 28 & 25,3 & 28,3 & 29,4 & 27,1 \\
$36-45$ év & 22,3 & 24,1 & 23,3 & 21,5 & 22,8 & 22,5 \\
$46-55$ év & 28,1 & 27,9 & 28,1 & 20,2 & 22,8 & 21,4 \\
\hline
\end{tabular}
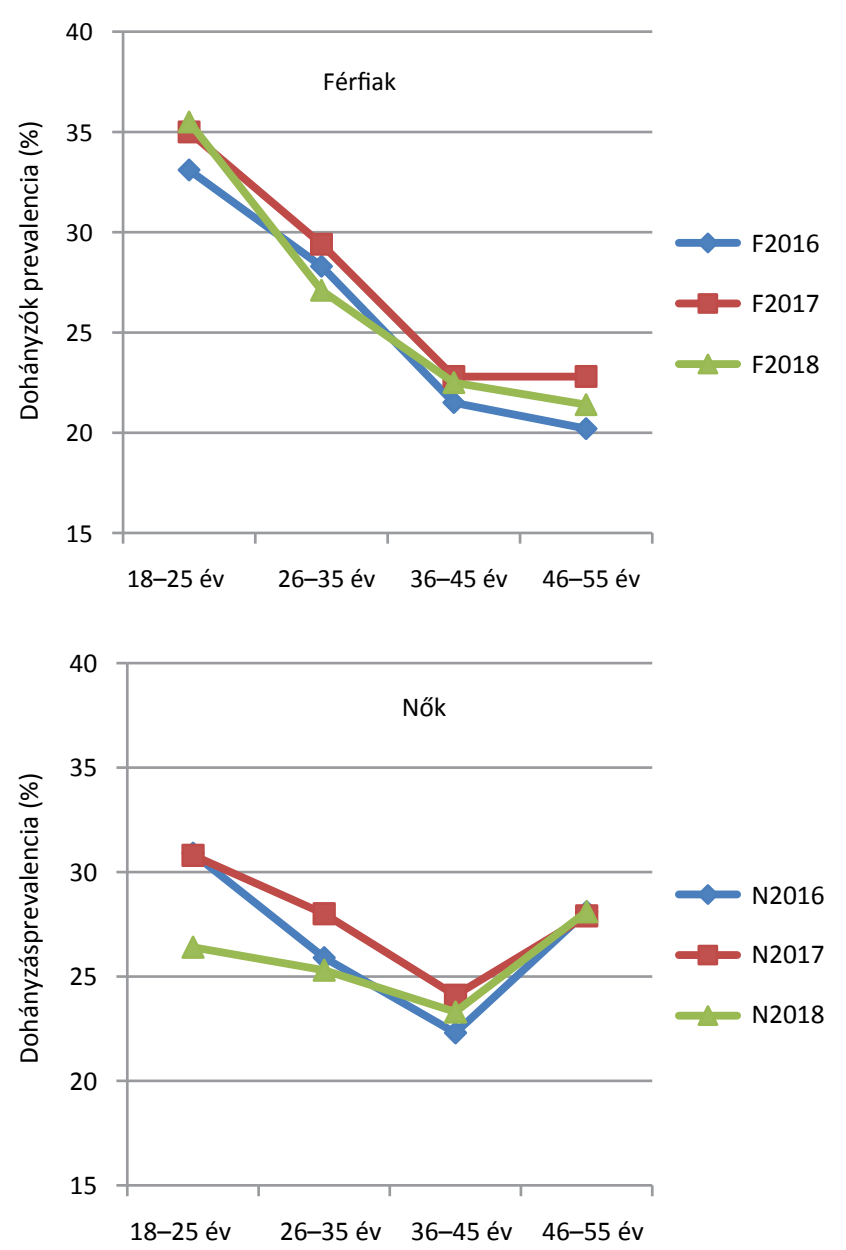

5. ábra $\mid$ A dohányzók arányának nemek szerinti összehasonlítása a 2016., 2017. és 2018. évben, a 18-55 éves életkorcsoportban

\section{Megbeszélés}

A dohányzás jól ismert kockázati tényezője számos cardiovascularis betegségnek, a krónikus obstruktív tüdőbetegségnek, tüdőcarcinomának $[2,4,9]$. Jellemző, hogy egyrészt a dohányzás közvetlen, azonnali egészségkárosító hatással is rendelkezik (vérnyomás- és szívfrekvenciaemelkedés, étvágytalanság, köhögés, légzésromlás, szédülés stb.), másrészt - rendszerint egy évtizeddel később - a dohányzással összefüggő halálozás is szignifikáns növekedést mutat $[5,18]$.

A dohányzás ma már a világ minden régiójában az egyik legnagyobb egészségkockázati tényezô, ennek megfelelően prevalenciája minden WHO-régióban igen magas. A 2018. évi WHO-riport [19] - mely az egész világra kiterjesztett, Global Adult Tobacco Survey adatait 
Korkorrigált dohányzásprevalencia 2000 és 2015 között a 15 évnél idősebb lakosság körében (WHO-adatok, 2018)

\begin{tabular}{lccc}
\hline Dohányzásprevalencia (\%) & Mindkét nem & Férfiak & Nók \\
\hline 2000 & 26,9 & 43 & 10,9 \\
2005 & 24,6 & 39,6 & 9 \\
2010 & 22,1 & 36,6 & 7,5 \\
2015 & 20,2 & 34,1 & 6,4 \\
\hline
\end{tabular}

WHO = Egészségügyi Világszervezet

3. táblázat | Korkorrigált, mindkét nemre vonatkozó dohányzásprevalencia WHO-régiókban, a 15 éven felüli lakosság körében 2015-ben (WHO-adatok, 2018)

\begin{tabular}{lll}
\hline Prevalencia (\%) & 2000 & 2015 \\
\hline Világ & 26,9 & 20 \\
Afrika & 12,6 & 10 \\
Amerika & 28 & 17,4 \\
Közel-Kelet + mediterrán országok & 19,3 & 18,1 \\
Európa & 37,3 & 29,9 \\
Délkelet-Ázsia & 24,1 & 17,2 \\
Nyugat-Csendes-óceáni régió & 29,9 & 24,8 \\
\hline
\end{tabular}

WHO = Egészségügyi Világszervezet

4. táblázat A dohányzás prevalenciája az Európai Közösség országaiban (EU-15) a 15 éven felüli populációban. Eurostat-adatbázis [18]

\begin{tabular}{lcccc}
\hline A mérés ideje & Mindkét nem & Nők & Férfiak & A mérés neve \\
\hline 2000 & 27,1 & 21,2 & 32,6 & EU-15 \\
2005 & 24,5 & 20,4 & 28,7 & EU-15 \\
2010 & 23,2 & 19,8 & 26,9 & EU-15 \\
2014 & 22,5 & 18,4 & 25,2 & EU-15 \\
\hline
\end{tabular}

5. táblázat $\mid$ A magyarországi dohányzásprevalencia a 18 éven felüli felnőtt populációban. Reprezentatív felmérések [14, 16, 21, 22]

\begin{tabular}{lcccc}
\hline A mérés ideje & Mindkét nem & Nők & Férfiak & A mérés neve \\
\hline 2000 & 32,4 & 26,1 & 40,3 & OLEF [21] \\
2005 & 28 & 23,3 & 33,9 & HEP [22] \\
2010 & 28 & 25,3 & 34,6 & OLAP [13] \\
2014 & 26,1 & 20,8 & 32 & ELEF [16] \\
\hline
\end{tabular}

ELEF = Európai Lakossági Egészségfelmérés; HEP = Helyi Esélyegyenlőségi Program; OLAP = online analitikai feldolgozás; OLEF = Országos Lakossági Egészségfelmérés

tartalmazza - alapján összeállítottuk a világ 2000 és 2015 közötti dohányzásprevalencia-tábláját mindkét nem vonatkozásában (2. táblázat). A dohányzás mértéke ezen 15 év alatt a férfiaknál mintegy 10\%-kal, a nőknél 5\%-kal csökkent. Férfiaknál a prevalencia minden évben jelentős mértékben nagyobb volt. Az összesített világ- adatok mögött azonban óriási különbségek állnak fenn a világ különböző régióiban (3. táblázat).

A riport rögzíti, hogy a globális csökkenés ellenére igazán jelentôs esést a dohánytermékek fogyasztásában csak az Amerikai Egyesült Államokban (USA) és Európában észleltek, az utóbbiban azonban a prevalencia 2015-ben mégis a világon a legmagasabb volt. DélkeletÁzsiában is jelentős volt a csökkenés, és itt mértek 2015ben az amerikaihoz hasonló méretû fogyasztást. Afrikában és Óceániában kisebb mértékű volt a változás, míg a közel-keleti + mediterrán régióban a prevalencia stagnált. Összességében a globális csökkenés ellenére ez rendszeresen dohányzó 175 millió nőt és 942 millió férfit jelent. Az Európai Közösségben (EU-15) a dohányzás prevalenciája a 2000 és 2014 közötti időszakban egyenletesen csökkent, a férfiak körében nagyobb mértékben (4. táblázat) [20].

Hazánkban Tombori és mtsai [14] 2010-ig összegezték a dohányzás előfordulásával foglalkozó felméréseket és tanulmányokat, majd az ELEF 2014. évi felmérése teszi teljessé az összehasonlítást (5. táblázat) [14, 16, $21,22]$. A dohányzás prevalenciájának csökkenése nem olyan egyenletes, mint azt a globális európai adatoknál láttuk, mert 2010-ben egy megtorpanását regisztrálták. Az összehasonlításoknál zavaró körülmény, hogy az európai mutatók a 15 év feletti, a magyar felmérések a 18 év feletti populáció adatait rögzítették. A legújabb Eurostat-adatbázis már lehetővé tette a reális összeurópai, illetve magyarországi adatok összehasonlítását 2014-ben - a jelenlegi 28 EU-tagállam adatai alapján -, melyet a 6. ábrán mutatunk be [15]. A teljes felnőtt populációban, illetve a férfiak és nők vonatkozásában egyaránt hazánkban szignifikánsan nagyobb a dohányzók aránya, szemben az európai közölt mérési adatokkal. A különbség a nők esetében nagyobb méretü.

A saját szűrôvizsgálatunkban 2010 és 2018 között évente figyeltük meg a dohánytermékeket rendszeres fo-

\begin{tabular}{lclc}
\hline & Mindkét nem & Nők & Férfiak \\
\hline EU-28 & 18,8 & 15,4 & 26,1 \\
HUN & 26,1 & 21 & 32 \\
\hline
\end{tabular}

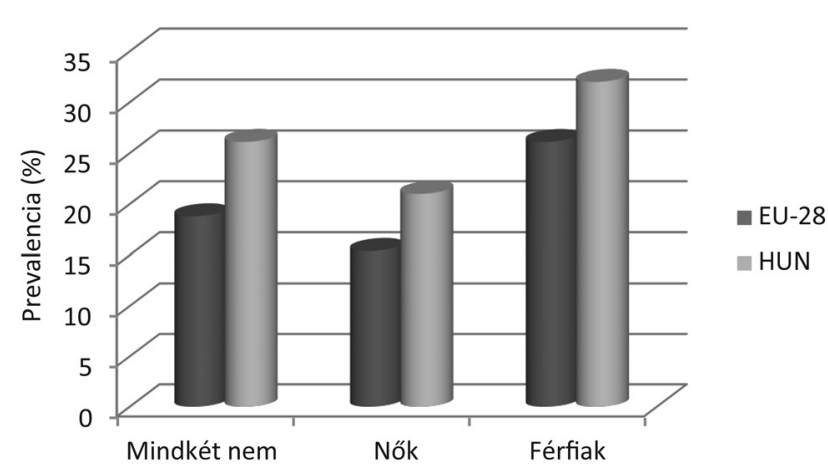

6. ábra (HUN) a 2014. évi felmérés alapján. Eurostat-adatbázis [15] 


\begin{tabular}{llllccc}
\hline & $18-24$ & $25-34$ & $35-44$ & $45-54$ & $55-64$ & $65-74$ \\
\hline EU-28 F & 22,1 & 29,6 & 27,8 & 25,8 & 22,2 & 12,2 \\
HUN F & 37 & 40,6 & 36 & 33,7 & 28,2 & 20,9 \\
EU-28 N & 16,4 & 19,2 & 15,9 & 20,5 & 16,8 & 8,4 \\
HUN N & 23,8 & 25,4 & 22,4 & 31,3 & 23 & 10 \\
\hline
\end{tabular}

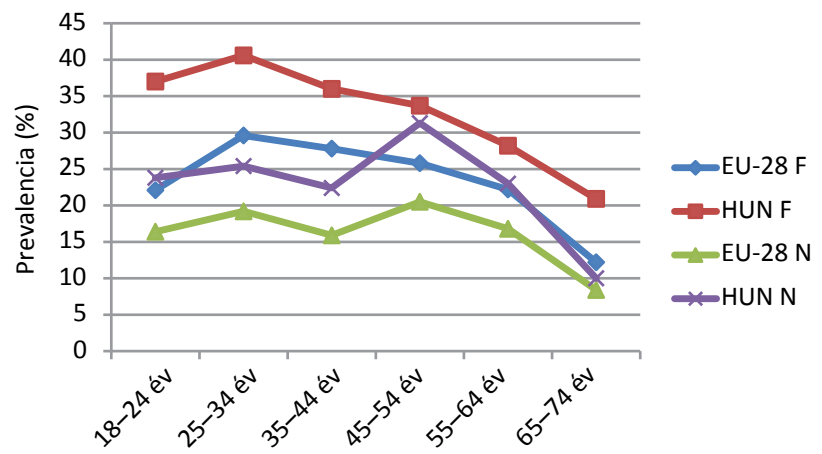

7. ábra

A dohányzás prevalenciája az Európai Unió 28 tagállamában és Magyarországon a nemi eloszlás és a korcsoportok alapján, 2014-ben

gyasztók arányát. Egyértelmúnek látszik, hogy a prevalencia 2010-ben volt a legmagasabb, majd 2012 és 2015 között egy fogyasztási hullámvölgy jelent meg, mely 2016-ban megszúnt, és újabb emelkedés alakult ki. A dohányzók aránya közötti különbséget az EU-tagországok (EU-28) és Magyarország között az egyes korcsoportokban is megvizsgáltuk a 2014. évi Eurostat-adatok alapján [15] (7. ábra). Az európai és a magyar reprezentatív felmérések teljesen megegyeznek az általunk 20162018-ban észleltekkel (5. ábra), mely szerint nőknél 45-54 év között van egy szignifikáns emelkedés. Ezt a jelenséget férfiak esetében nem észlelték. Az egyes életkorcsoportok alapján végzett elemzéseink szerint mindkét nemben 18-25 év között volt a legnagyobb a rendszeresen dohányzók száma, a férfiaknál szignifikánsan nagyobb mértékben. A fiatal korcsoportban észlelt magas előfordulást esetleg ezen korcsoport relatíve alacsonyabb szúrési megjelenési létszáma is okozhatta. Ennek ellentmond, hogy a fiataloknál észlelt magas dohányzási prevalenciát - a miénkhez hasonlóan - az egyébként alacsony átlagprevalenciát mutató országokban (USA, Anglia) is észlelték $[23,24] .26$ évtől a férfiaknál egyenletes csökkenés alakul ki, de a nőknél - átmeneti csökkenés után - 45-56 év között újabb, szignifikáns növekedést láttunk. A dohányzók aránya 56 éves kor után mindkét nemben rohamosan csökkent. Tombori és mtsai [13] a dohányzók arányát a 35-44 éves korban találták a legnagyobbnak.

Természetesen az egyes országok, régiók közötti különbséget számos tényező befolyásolja, mint az ökoszociológiai különbségek, a gazdasági fejlettségi szint, speciális életformák, etnikai eltérések stb. A csökkenő tendenciát mindezeken túl jelentősen befolyásolják az egyes országok egészségpolitikai törekvései a dohányzás mint életforma ellen (speciális oktató-nevelő programok, dohánymentes területek, figyelmeztető feliratok a termékeken, médiakampányok, termékadó stb.) [25].

Fontosnak és aggasztónak tartjuk, hogy a férfiak és nók közötti dohányzási arány közel került egymáshoz. Ez azt jelenti, hogy - más európai országokban észleltekhez hasonlóan - a dohányzó nők gyakorisága összességében is megnövekedett [13]. A nőknél észlelt megfigyeléseink - a 26-35. életév közötti dohányzáscsökkenés, majd a 36-45 év közötti növekedés - külön magyarázatot igényelnek. A csökkenés oka lehet, hogy erre az időszakra esik a legtöbb terhesség, gyereknevelés. Ezt igazolja Lange és mtsai 2018. évi világméretû felmérése [26], mely szerint Európában a terhes nők körében szignifikánsan alacsonyabb a dohányzók gyakorisága a teljes nôi populációhoz képest $(8,1 \%$, illetve $15,1 \%)$. Bödecs és mtsai reprezentatív felmérését figyelembe véve, hazánkban hasonló az arány (12,6\%, illetve 20,7\%) [27].

A nők esetében 40-45 éves korban kialakuló újabb fogyasztásnövekedés mögött a legvalószínúbb ok a posztmenopauza időszakában kialakuló - sokszor jelentős testsúlynövekedés, mely ellen az egyik leggyakrabban használt módszer a dohányzás [28], mert csökkenti az étvágyat és testsúlycsökkenéshez vezet [29], ugyanakkor növeli a középkorú nők mortalitását [30]. Ezek a tények indokolják, hogy az eddigieknél is nagyobb mértékben szükséges az orvosi praxisban és azon kívül is folyamatosan folytatni a dohányzás elleni küzdelmet, annál is inkább, mert a nők érzékenyebbek a nikotinnal szemben $[31]$.

Anyagi támogatás: A közlemény megírása anyagi támogatásban nem részesült.

Szerzői munkamegosztás: K. E.: A közlemény írása. B. I.: Szövegezés, adatellenőrzés. D. T.: Statisztikai elemzés. D. G.: Programkivitelező. A cikk végleges változatát valamennyi szerző elolvasta és jóváhagyta.

Érdekeltségek: A szerzőknek nincsenek érdekeltségeik.

\section{Irodalom}

[1] Centers for Disease Control and Prevention. How tobacco smoke causes disease: the biology and behavioral basis for smoking-attributable disease: a report of the surgeon general. Part 7. Pulmonary diseases. CDC, Atlanta, GA, 2010. Available from: www.ncbi.nlm.nih. gov/books/NBK53021/.

[2] Brunner H, Cockcroft JR, Deanfield J, et al. Endothelial function and dysfunction. Part II: Association with cardio vascular risk factors and diseases. A statement by the Working Group on Endothelins and Endothelial Factors of the European Society of Hypertension. J Hypertension 2005; 23: 233-246.

[3] Trap-Jensen J. Effects of smoking on the heart and peripheral circulation. Am Heart J. 1988; 115: 263-267.

[4] Esen AM, Barutcu I, Acar M, et al. Effect of smoking on endothelial function and wall thickness of brachial artery. Circ J. 2004; 68: 1123-1126.

[5] Kékes E. Cardiovascular risk factors and risk assessment. [Cardiovascularis kockázati tényezők és kockázatbecslés.] LAM 2013; 23: 489-501. [Hungarian] 
[6] Zhang WZ, Venardos K, Chin-Dusting J, et al. Adverse effects of cigarette smoke on NO bioavailability: role of arginine metabolism and oxidative stress. Hypertension 2006; 48: 278-285.

[7] Kao PC, Shiesh SC, Wu TJ. Serum C-reactive protein as a marker for wellness assessment. Ann Clin Lab Sci. 2006; 36: 163 169.

[8] Green MS, Jucha E, Luz Y. Blood pressure in smokers and nonsmokers: epidemiologic findings. Am Heart J. 1986; 111 : 932 940.

[9] Walser T, Cui Y, Yanagawa J, et al. Smoking and lung cancer. Proc Am Thorac Soc. 2008; 5: 811-815.

[10] Bhatt SP, Kim Y, Harrington KF, et al. Smoking duration alone provides stronger risk estimates of chronic obstructive pulmonary disease than pack-years. Thorax 2018; 73: 414-421.

[11] Kékes E, Páll D. Combined antihypertensive and antilipid treatment in smoking hypertensive patients with high risk. [Optimális kezelési stratégia ischaemiás szívbetegséggel, perifériás érszûkülettel, diabetesszel társult, vagy dohányzó hypertoniás betegekben.] Hyperton Nephrol. 2015; 19: 202-207. [Hungarian]

[12] GBD 2015 Tobacco Collaborators. Smoking prevalence and attributable disease burden in 195 countries and territories, 19902015: a systematic analysis from the Global Burden of Disease Study 2015. Lancet 2017; 389: 1885-1906.

[13] Demjén T, Kiss J, Viski D. World Health Organization Framework Convention on Tobacco Control: Hungarian reports. [Egészségügyi Világszervezet Dohányzás-ellenőrzési Keretegyezmény: magyar országjelentések.] Egészségfejlesztés 2017; 58 60-67. [Hungarian]

[14] Tombori I, Paksi B, Urban R, et al. Epidemiology of smoking in Hungary - a national representative study. [A dohányzás epidemiológiája a magyar népesség körében országos reprezentatív adatok alapján.] Orv Hetil. 2010; 151: 330-337. [Hungarian]

[15] Eurostat. Daily smokers of cigarettes by sex, age and educational attainment level [hlth_ehis_sk3e]. Last update: 21-03-2019.

[16] European Population Health Survey, 2014. [Európai lakossági egészségfelmérés (ELEF), 2014.] KSH Statisztikai Tükör 2015; 29: 1-9. [Hungarian]

[17] Barna I, Daiki T, Kékes E, et al. First nine year results of "Comprehensive Health Screening of Hungary 2010-2020-2030". [Magyarország Átfogó Egészségvédelmi Szúroóprogramja 20102020-2030 (MÁESZ) eredményei 2010-2018, az első kilenc év.] LAM 2019; 29: 111-119. [Hungarian]

[18] Agaku IT, King BA, Husten CG, et al. Tobacco product use among adults - United States, 2012-2013. Morb Mortal Wkly Rep. 2014; 63: 576-686.
[19] WHO global report on trends in prevalence of tobacco smoking 2000-2025, 2nd edition. World Health Organization, Geneva, 2018. ISBN 978-92-4-151417-0

[20] WHO. European Health Information Gateway. European Health for All database (HFA-DB). Regular daliy smokers in the popuilation age 15+. Updated: 15 June 2018.

[21] Boros J, Németh R, Vitrai J. National Population Health Survey, OLEF 2000. [Országos Lakossági Egészségfelmérés, OLEF 2000.] Országos Epidemiológiai Központ, Budapest, 2002. [Hungarian]

[22] Susánszky E, Szántó Zs, Kopp M. Analyis of motivations of smoking cessation. [A dohányzásról való leszokás motivációs hátterének vizsgálata.] LAM 2007; 17: 616-621. [Hungarian]

[23] Wang TW, Asman K, Gentzke AS, et al. Tobacco product use among adults - United States, 2017. Morb Mortal Wkly Rep. 2018; 67: 1225-1232.

[24] ASH Fact Sheet on: Smoking statistics. Who smokes and how much. February 2016. www.ash.org.uk

[25] World Health Organization. WHO report on global tobacco epidemic 2017. WHO, Geneva. Available from: https://www. who.int /tobacco/global_report/2017/en [accessed: August 21, 2019].

[26] Lange S, Probst C, Rehm J, et al. National, regional, and global prevalence of smoking during pregnancy in the general population: a systematic review and meta-analysis. Lancet Glob Health 2018; 6: e769-776. Supplementary appendix pp. 1-36.

[27] Bödecs T, Horváth B, Szilágyi E, et al. Effects of depression, anxiety, selfesteem, and health behaviour on neonatal outcomes in a population-based Hungarian sample. Eur J Obstet Gynecol Reprod Biol. 2011; 154: 45-50.

[28] Jung SY, Vitolins MZ, Fenton J, et al. Risk profiles for weight gain among postmenopausal women: a classification and regression tree analysis approach. PLoS ONE 2015; 10(3): e0121430.

[29] Chiolero A, Faeh D, Paccaud F, et al. Consequences of smoking for body weight, body fat distribution, and insulin resistance. Am J Clin Nutr. 2008; 87: 801-809.

[30] Gram IT, Sandin S, Braaten T, et al. The hazards of death by smoking in middle-aged women. Eur J Epidemiol. 2013; 28: 799-806.

[31] Sofuoglu M, Mooney M. Subjective responses to intravenous nicotine: greater sensitivity in women than in men. Exp Clin Psychopharmacol. 2009; 17: 63-69.

(Kékes Ede dr., Pécs, Ifjúság útja 13., 7624 e-mail: kekesede@gmail.com)

\section{"De gustibus non est disputandum." (Az ízlésről nincs mit vitatkozni.)}

A cikk a Creative Commons Attribution 4.0 International License (https://creativecommons.org/licenses/by/4.0/) feltételei szerint publikált Open Access közlemény, melynek szellemében a cikk bármilyen médiumban szabadon felhasználható, megosztható és újraközölhető, feltéve, hogy az eredeti szerzỏ és a közlés helye, illetve a CC License linkje és az esetlegesen végrehajtott módositások feltüntetésre kerülnek. (SID_1) 